\title{
REMOTE SENSING USING UNMANNED AERIAL VEHICLES FOR TOURIST-RECREATION LAKE EVALUATION AND DEVELOPMENT
}

\author{
GRZEGorz BorKowsKi ( ${ }^{1}$, AdAM MŁYNARCZYK @ ${ }^{2}$ \\ ${ }^{1}$ Department of Tourism and Recreation, Adam Mickiewicz University in Poznań, Poland \\ ${ }^{2}$ Department of Soil Science and Remote Sensing of Soils, Adam Mickiewicz University in Poznań, Poland
}

Manuscript received: January 8, 2019

Revised version: March 5, 2019

\begin{abstract}
BorKOWSKi G., MŁYNARCZYK A., 2019. Remote sensing using unmanned aerial vehicles for tourist-recreation lake evaluation and development. Quaestiones Geographicae 38(1), Bogucki Wydawnictwo Naukowe, Poznań, pp. 5-14. 11 figs, 1 table.

ABSTRACT: This article concerns the use of remote sensing methods to assess the potential of tourism and recreation of lakes by using unmanned aerial vehicles as a tool that offers new measurement possibilities in such difficult areas to research as river and lake systems. For the purpose of the study, air surveys over three lakes used for tourism and recreation purposes were planned and carried out. These were the following lakes: Swarzędzkie, Wolsztyńskie and Zbąszyńskie located in western Poland. The photos were taken with a RGB and a multispectral cameras. On the basis of calculated orthophotomaps and digital surface models, anthropogenic and natural values were assessed. The examples of the research show the versatile possibilities of using drones dependent on the type sensor used. Remote sensing performed from the deck of an unmanned aircraft is widely used in the study of lakes and is an alternative to existing land and water research methods.
\end{abstract}

KEY WORDS: remote sensing, drone, lake, tourism, recreation

Corresponding author: Grzegorz Borkowski, grzegorz.borkowski@amu.edu.pl

\section{Introduction}

The development of new technologies has made it possible to carry out both field and chamber scientific research in a way that until recently seemed impossible, as well as provide measurement methods to assess the geographical environment from an entirely different perspective. This revolution in remote sensing research is especially enabled by the relatively new ability to perform measurements using unmanned aerial vehicles.

Unmanned Aerial Vehicles (UAVs), commonly known as drones and according to the European
Commission recommendations Remotely Piloted Aircraft Systems (RPAS), provide many measurement possibilities depending on the sensors attached to them. These may include thermometers, hygrometers, laser scanners, cameras in the range of visible lights and infrared. Each object reflects electromagnetic radiation in a characteristic manner, and the graph of such a reflection is called the spectral curve. The spectral vegetation curve in the visible range $(0.4-0.7 \mu \mathrm{m})$ has minima in the range of blue $(0.4-0.5 \mu \mathrm{m})$ and red $(0.6-$ $0.7 \mu \mathrm{m})$ and maximum in the green range $(0.5-0.6$ $\mu \mathrm{m})$ (Fig. 1) (Zawiła-Niedźwiecki 2010). The use of a spectral curve for plants makes it possible to 


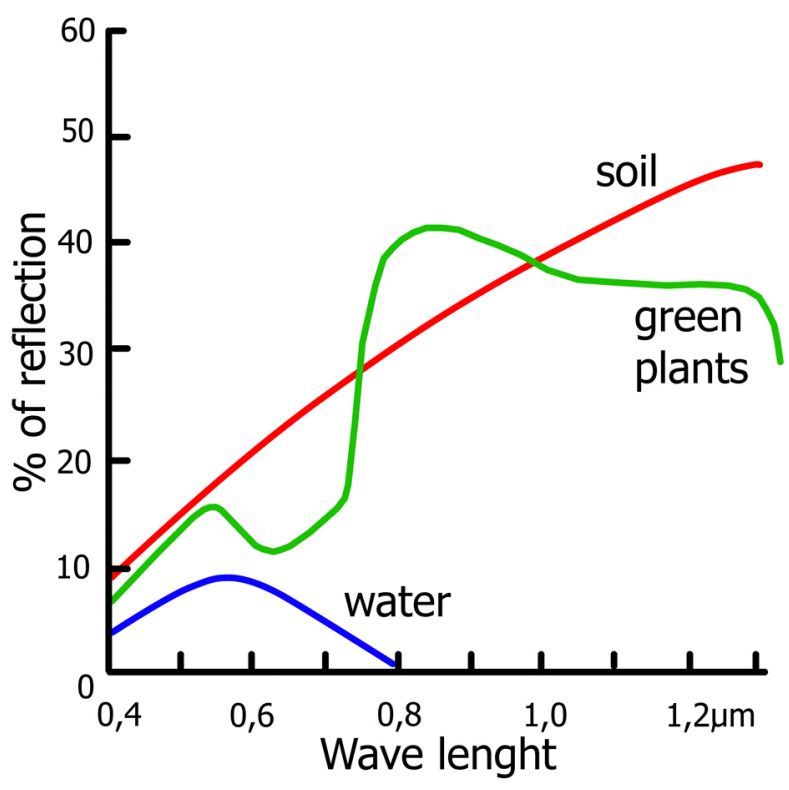

Fig. 1. Standard spectral reflection curves of soil (red), vegetation (green) and water (blue) (ZawiłaNiedźwiecki 2010).

assess the vegetation cover and the course of the shoreline among the reeds.

UAVs are typically low cost, light weight and low airspeed aircraft that are well suited for remotely sensed data gathering (Wójtowicz et al. 2016). An important factor affecting the availability of this technology is its affordability, especially when compared to manned aircraft or satellites, as well as the much simpler service needed for the current generation of drones compared to earlier versions. The UAV itself can be of various sizes, have different maximum take-off mass (MToM), as well as a variable number of rotors, e.g. four, six or eight-rotor. Technological progress in recent years has led to increased availability of lowcost UAVs (Strejczek-Jaźwińska et al. 2018).

Another factor is the high availability of diversified software for post-processing of acquired data and mobile applications used during air operations. For scientific research this means unmanned aerial vehicles can be used for remote sensing, photogrammetry, mapping of the natural environment, geodesy, topography, cartographic visualization, development of an orthophotomap and many other research areas. One of the comprehensive applications of drones is their ability to assess river and lake systems, which due to their specificity are often difficult to access from land or even water.

\section{Conditions suitable for conducting test sites using unmanned aircraft}

The conditions related to the implementation of aviation operations using UAVs can be divided into legal, natural and equipment related. The provisions of Polish law provide for two cases of UAVs flights: recreational and sport flights (do not require a certificate of qualification) and others (including research) require a certificate of qualification of the flight staff. Air operations are divided into:

- flights within sight - Visual Line Of Sight (VLOS), which can be performed without reporting to the appropriate governing body of air traffic (in Poland it is the Polish Air Navigation Services Agency) and

- flights out of sight - Beyond Visual Line Of Sight (BVLOS) - performed in the declared, separate airspace. In each country, there are aviation zones where UAV are prohibited operation and those in which flights are possible on the basis of the zone management are allowed.

The drone operator (Unmanned Aerial Vehicle Operator - UAVO) performing tests must have a qualification certificate issued by the Civil Aviation Office, a medical certificate, mandatory liability insurance of a UAV pilot and a reflective vest, while the drone must be equipped with a nameplate with the operator's data, as well as Return To Home (RTH) function, which at the moment of breaking the transmission, the UAV Transmitter returns the equipment safely to its starting point.

In order to be able to carry out the UAV operation for acquiring photographs, account should be taken of weather conditions prevailing over the area under investigation. Factors such as strong wind, precipitation or frost can hinder or even prevent UAV operations. The best lighting is found at the moment of sun-shading and the greatest possible scattering of the sun's rays. Clouds scattering solar radiation create ideal conditions for the pictures taken, eliminating the shadow in the area under investigation. Moving shadows cause problems with determining characteristic points, when post-processing images are combined. 


\section{Aim, scope and methods of research}

The purpose of this article is to present the possibilities of remote sensing methods using unmanned aerial vehicles to assess the values and development of tourism and recreation of lake areas. The research was carried out in the summer seasons in 2017 and 2018 at the lakes: Swarzędzkie, Wolsztyńskie and Zbąszyńskie, located in the Wielkopolska-Kujawskie Lakeland in western Poland. Lakes Swarzędzkie and Wolsztyńskie are located within the popular tourist destinations of Swarzędz and Wolsztyn, respectively, while due to its morphometric parameters, Lake Zbąszyńskie is a reservoir willingly used for water recreation.

The presented research used a UAV DJI Phantom 3 Advance, having four rotors, $\mathrm{MToM}=$ $1280 \mathrm{~g}$, capable of moving in wind up to $10 \mathrm{~m} / \mathrm{s}$, field of view $(\mathrm{FOV})=94^{\circ}$, with $12 \mathrm{MP}$ camera (Phantom 3 2015). The maximum height to which you can take pictures including this UAV is $500 \mathrm{~m}$ AGL (Above Ground Level) and maximum 6000 $\mathrm{m}$ above sea level (ASL). The flight operations for the needs of the research were carried out in sight in the aviation zone $\mathrm{G}$, in which UAV traffic is allowed. The photos were taken from a height of 30 $\mathrm{m}$ AGL with $\mathrm{FOV}=94^{\circ}$ for a matrix of 12 MPix $(4000 \times 3000 \mathrm{px})$. After the calculations, the field of view of the camera-remote sensing sensor was theoretically $(64.3 \times 48.2 \mathrm{~m})$, which is equivalent to the real pixel dimension of $1.6 \times 1.6 \mathrm{~cm}$. To increase resolution, the flight can be lowered or a higher resolution camera used. Water is a very difficult object in terms of photogrammetry because of its movement, homogenity and impossibility of correct connection between photos in photogrammetric programs, therefore in this study additional photos were taken from a $500 \mathrm{~m}$ AGL ceiling for reproduction on the model. For the visual evaluation of the values and tourism and recreational development of lakes and blooms, the camera was used in visible range, while for assessment of the coastline and vegetation a multispectral camera at wavelengths: $440 \mathrm{~nm}, 560 \mathrm{~nm}$, $660 \mathrm{~nm}, 700 \mathrm{~nm}, 780 \mathrm{~nm}, 842 \mathrm{~nm}$ and $865 \mathrm{~nm}$ was used. In the photos, each pixel is assigned a value determining the level of their brightness, which is proportional to the amount of reflected radiation reaching the remote sensing sensor (Piekarczyk, Kaźmierowski 2015).
The data obtained during measurements were completed in the post-processing. Typical photogrammetric products include an orthophotomap and a digital model of the surface area. In order to obtain a high resolution orthophotomap, the photos were taken from a low ceiling. During flight planning and camera settings, factors such as altitude, exposure time, aperture and sensitivity were taken into account, which had a direct impact on determining the speed of movement of the unmanned aircraft. The UAV records GPS and IMU data for an autonomous flight to predefined camera positions (waypoints) (Eltner et al. 2015). In order for the model made from the photographs to be photogrammetric, an optimal coverage of photos of the studied area was taken, which was $90 \%$, which means that photographed point could be on 81 photographs. Photographs were taken in a vertical projection and at an angle of 70 degrees in four directions, in order to obtain more accurate 3D content. An important aspect taken into account when planning a flight was the variability of the height of the terrain. For the study area, photos were taken by moving the drone in a horizontal plane, because the terrain around it had a small variation in altitude. To maintain a constant distance from the ground level, the numerical terrain model that will calculate the actual altitude in the shooting software can be used. During flight over lakes with flat edges, no altitude correction is required, which allows flight at a constant altitude, which fluctuates, for the examined case, within 28-30 m AGL.

Knowing the size of the matrix, the size of the examined pixel can be calculated, which during the current research was about $1.6 \mathrm{~cm}$ for the ground. The higher the object, the closer it was to the camera, which increased the resolution of the model but also reduced the coverage. Each photo has information stored in the EXIF from the satellite navigation receiver mounted on the drone and information on the time of exposure, aperture, focal length, sensitivity, camera model and others.

After the photos were taken, they were uploaded to Photoscan, in which the following tasks were performed:

- entering calibration information. Calibration information was obtained for each camera using a calibration chart for which pictures 
were taken. Photoscan calculated radial and tangential distortion of the lens and matrix, which further determine the accuracy of the obtained model and made it easier for the program to properly combine images,

- align photos - this is the process during which the binding points forming the basis for placing the camera position on the model in the appropriate place in space are detected in the pictures. Information coming from EXIF is only a simplification for the program, while precise calculations are carried out using tie points,

- optimize alignment - corrections to the align process are included using the camera calibration file,

- dense cloud - this process builds a point cloud on the basis of arranged photos using mathematical relationships between the position of the point in space and the point on the plane of the image. Each point from the cloud was assigned three coordinates in the adopted coordinate system. An additional attribute was colour,

- Digital Surface Model (DSM) - based on the point cloud, a digital surface model was calculated in the assumed reference plane (Fig. 2). In the Figure 2, the path of passage is also visible,

- orthophotomap - created by assembling geometrically corrected individual photos to form a mosaic (Królewicz et al. 2015). Then, individual images are assembled to form a continuous orthophotomap, which was developed for each of the studied lakes.

To identify the shoreline running in the reed-covered area of lakes, aerial photographs made with a multi-spectral camera were used. For the study, nearly ultraviolet $(0.3-0.4 \mu \mathrm{m})$, the entire visible range $(0.4-0.7 \mu \mathrm{m})$ and near infrared $(0.7-1.3 \mu \mathrm{m})$ were recorded. Photos were analysed:

- on the basis of spectral images, histograms showing the brightness distribution at the land-water interface were developed;

- on the basis of remote-sensing and photogrammetric tests, the course of the shoreline was determined.

\section{The range of test sites}

The research on the possibility of using unmanned aerial vehicles to assess the values of tourism and recreational development of lakes was done over three reservoirs located in the Lakeland of Wielkopolska and Kujawy in western Poland (Fig. 3). The lakes of: Swarzędzkie, Wolsztyńskie and Zbąszyńskie - fluvial, with post-glacial origins, formed in alleröd (Borkowski 2014).

Morphometric data of the tested areas is presented in Table 1.

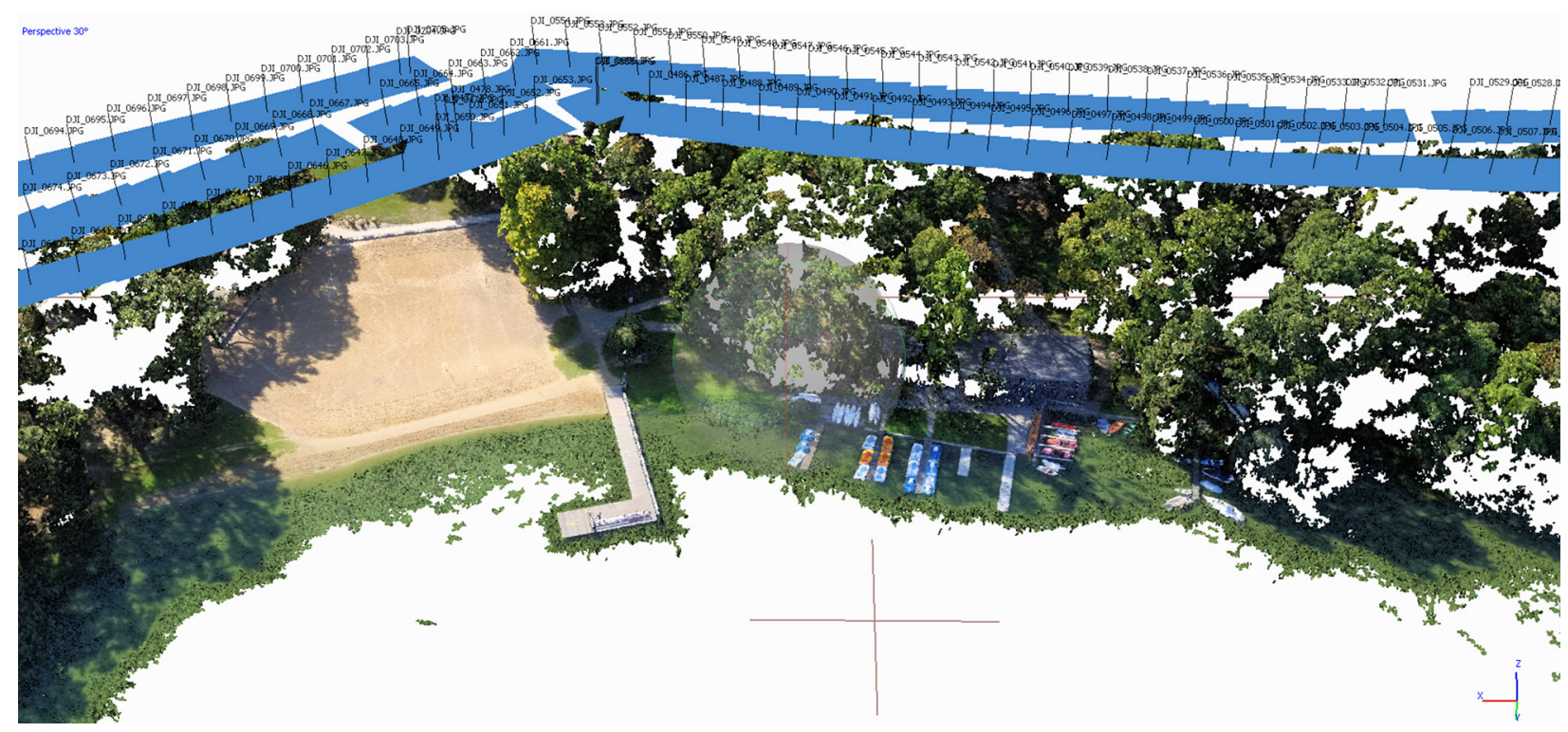

Fig. 2. Visualization of flight over the area of research (Lake Zbąszyńskie) and the generated three-dimensional model in Photoscan. 


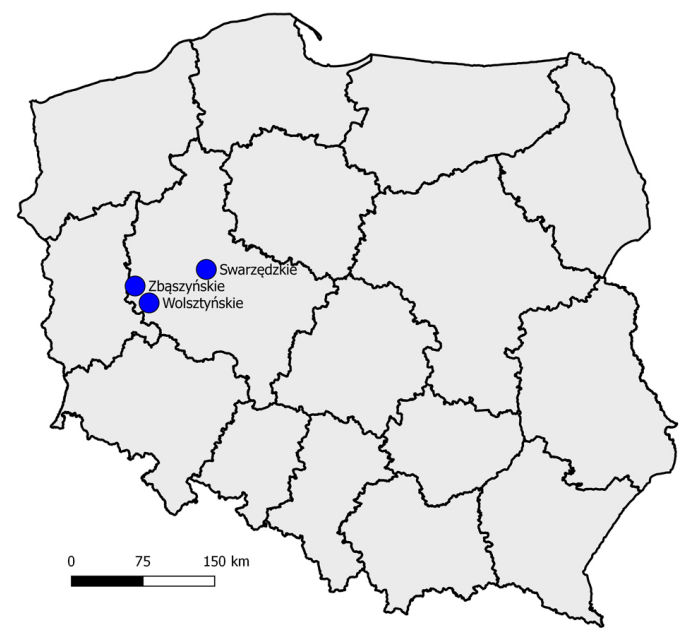

Fig. 3. Location of the lakes investigated on the background of the administrative division of Poland.

These reservoirs, due to their location near cities, are used for tourism and recreation. The Lake Swarzędzkie is located in the centre of Swarzędz a town of 30,000 inhabitants. Water in this reservoir is characterized by eutrophy, which makes bathing in the summer impossible. Around the reservoir there are sport and recreation complexes: a

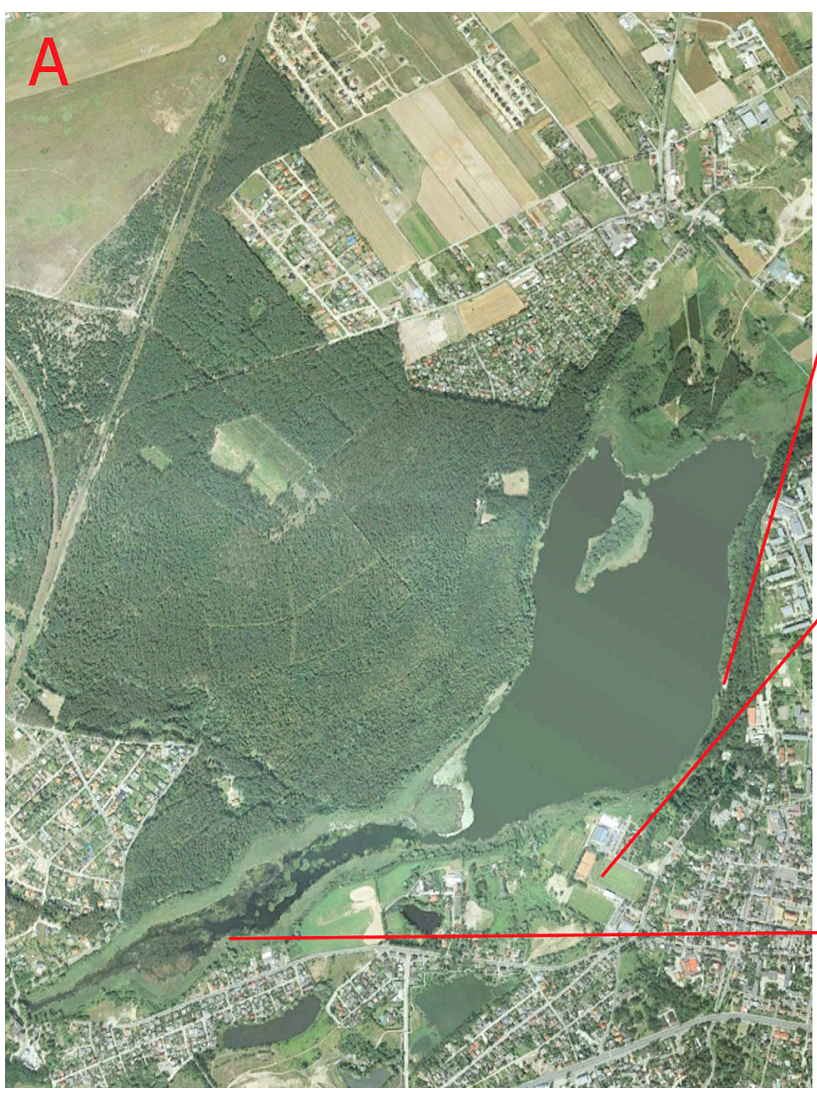

Table. 1. Morphometric data of the lakes studied.

\begin{tabular}{|l|c|c|c|}
\hline Name of lake & Area [ha] & Average depth [m] & River \\
\hline Swarzędzkie & 94 & 2.6 & Cybina \\
\hline Wolsztyńskie & 120 & 2.0 & Dojca \\
\hline Zbąszyńskie & 684 & 3.2 & Obra \\
\hline
\end{tabular}

swimming pool, playgrounds, an ice rink, sport fields, pedestrian and bicycle routes as well as a marina for sailing boats (Fig. 4).

The largest town on Lake Wolsztyńskie is Wolsztyn with 13,000 inhabitants, in which an interesting pier was built connected with the promenade (Fig. 5).

At the lake is a historic park with a palace, several beaches and the headquarters of a canoe club. The largest of the water reservoirs studied is the Lake Zbąszyńskie, the last from the 6 so-called Lakes Zbąszyńskie through which the Obra River flows. It is the fourth largest water reservoir in the Wielkopolska-Kujawskie Lakeland. According to the analysis made by Choiński, Borkowski (2008), due to the surface, the lake is also distinguished by other parameters: in Wielkopolska, the Lake Zbąszyńskie is 5 th in terms of maximum
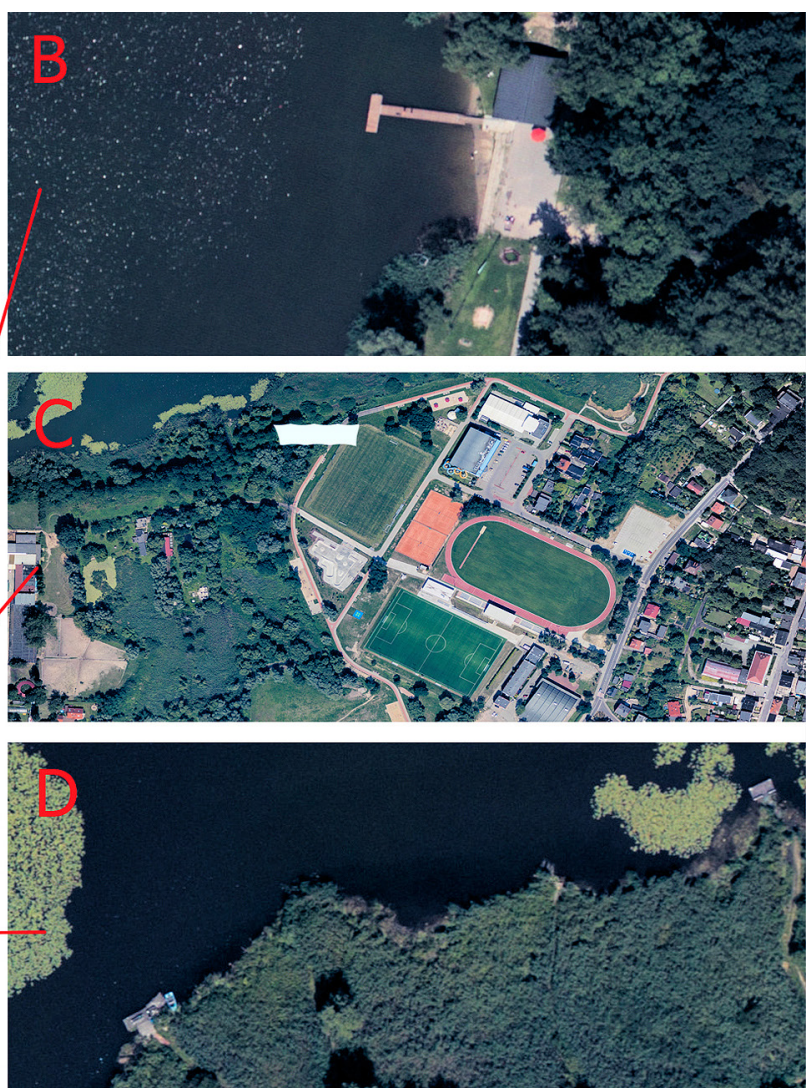

Fig. 4. Tourist and recreational infrastructure of the Lake Swarzędzkie.

A - Lake Swarzędzkie (https://www.google.pl/maps), B - swimming pool, C - sports and recreation complex, D - Cybina outflow from the lake. 

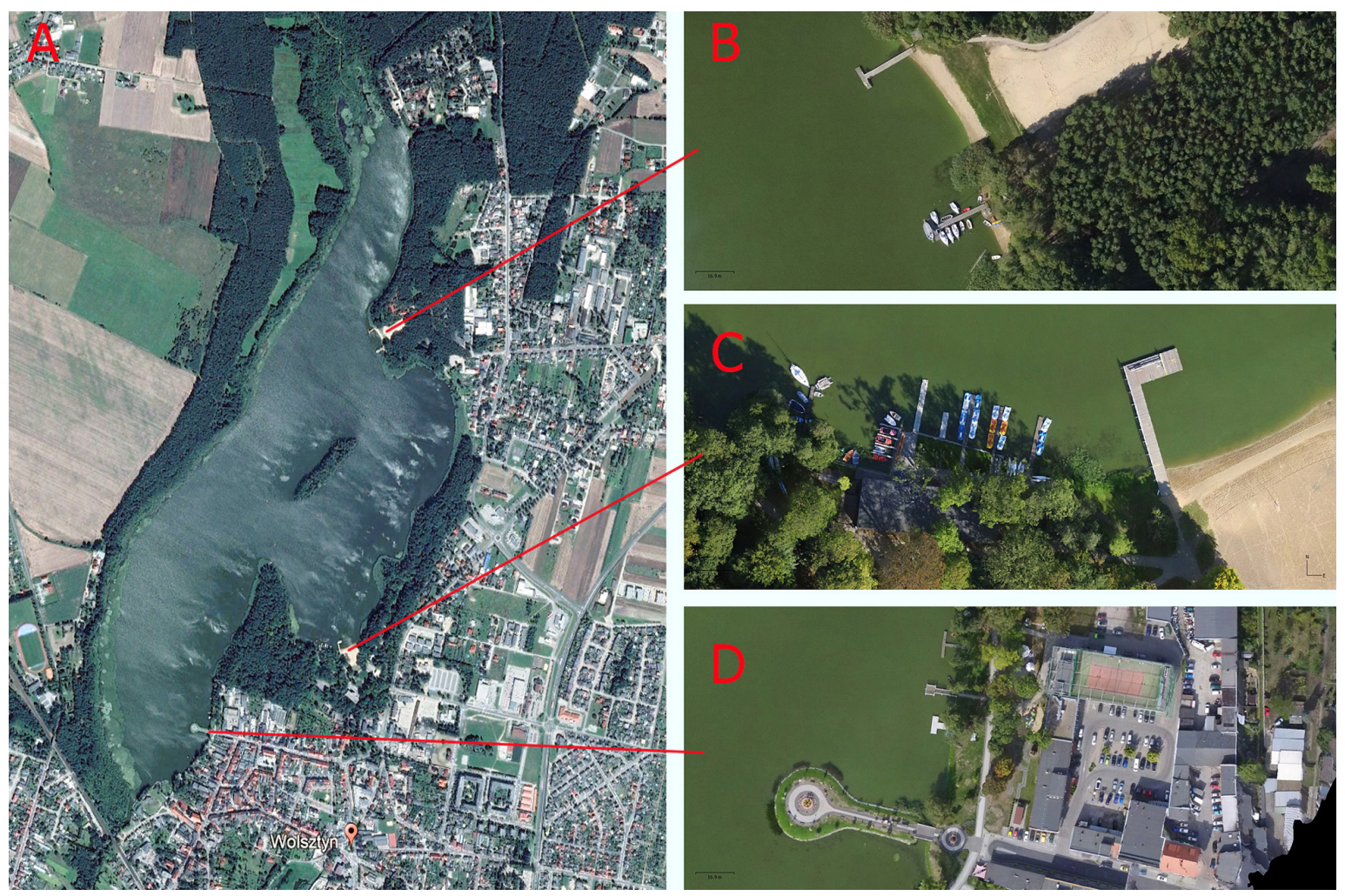

Fig. 5. Tourist and recreational infrastructure of Lake Wolsztyńskie.

A - Lake Wolsztyńskie (https:/ / www.google.pl/maps), B - swimming pool, C - swimming pool with marina and city beach, D - pier.
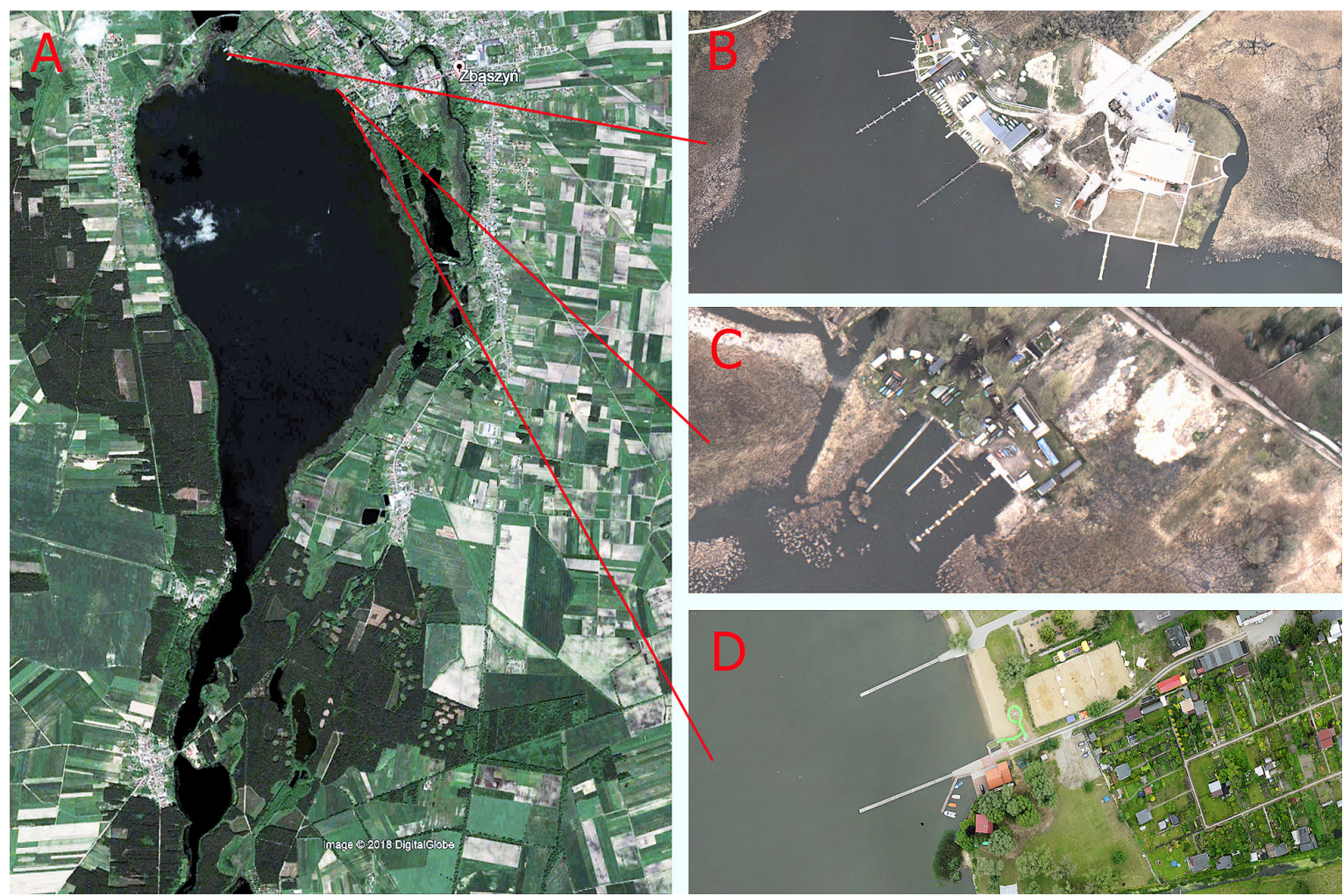

Fig. 6. Tourist and recreational development of the Lake Zbąszyńskie.

A - Lake Zbąszyńskie (https:/ / www.google.pl/maps), B - marina and swimming pool (photo: M.Wyczałek), $\mathrm{C}$ - a fish farm (photo: M. Wyczałek), D - swimming pool and city beach. 
width $-2205 \mathrm{~m}$ and 5 th due to the weakest development of the shoreline $25 \mathrm{~m} \times \mathrm{ha}^{-1}$, 8th in terms of average width $-1045 \mathrm{~m}$, 14th in terms of water resources, 10th in maximum length $-7105 \mathrm{~m}$ and an exposure indicator of 112. Around the lake are located several beaches, resorts, a hotel, a promenade (Fig. 6). There is also a canoe trail running through the lake named after Karol Wojtyła. Due to its size and surface, this area is a popular place for sailing, canoeing and windsurfing.

\section{Examples of possibilities of assessing the values and tourism and recreational development of lakes}

All three analysed reservoirs have rivers flowing into and out of them within which canoeing is cultivated. Water routes are marked and described in the literature, while the routes actual condition is difficult to verify, because there is no current information on the availability of banks, nuisances in the form of e.g. fallen trees or the degree of overgrowth by submerged, floating and rush vegetation. An inventory of canoe routes has shown that there are many places within the river and lake systems under investigation, where there are nuisances for canoeists. These difficulties are usually caused by inadequate maintenance of navigability of waterways, in particular in the zones of influence and outflow of watercourses from lakes. This applies to Lake Wolsztyńskie (Fig. 7A) and Swarzędzkie.

The waterway through the Lake Zbąszyńskie is well maintained, although the accessibility of the banks is not the best (Fig. 7B). There are problems with crossing the entire route of Karol Wojtyła, however, which concerns the remaining so-called Lakes Zbąszyńskie and the Obra River.

Aerial photographs of recreational infrastructure located on the lakes make it possible to assess its condition and monitor the degree of wear both during the bathing season and in winter conditions when the water is frozen. In addition, they provide the ability to monitor the status of platforms, as well as the emission of oil-derived pollutants to water from boat engines moored at marinas (Fig. 8).

An important element in the use of recreational lakes is the quality of water, specified in the Regulation of the Minister of Health on the supervision of the quality of bathing water and the place used for bathing. According to legal requirements, water should be subject to ongoing quality assessment, which includes, among others visual supervision. In this way, the blooms of cyanobacteria (streaks, scum, foam) are assessed, the occurrence of which prevents bathing in the lake. The assessment of the occurrence, extent and direction of flowering movement was made for Lake Wolsztyńskie from the height of $500 \mathrm{~m}$ AGL. In Figure 9, you can notice not only the fact of blooms, but also the direction of movement and the scale of this phenomenon.

A comprehensive view of the infrastructure of the areas around the water reservoirs enables a map showing the entire lake. The development of current maps for such large areas is difficult, labour and cost-intensive, which is why generally available aerial photographs or orthophotomaps
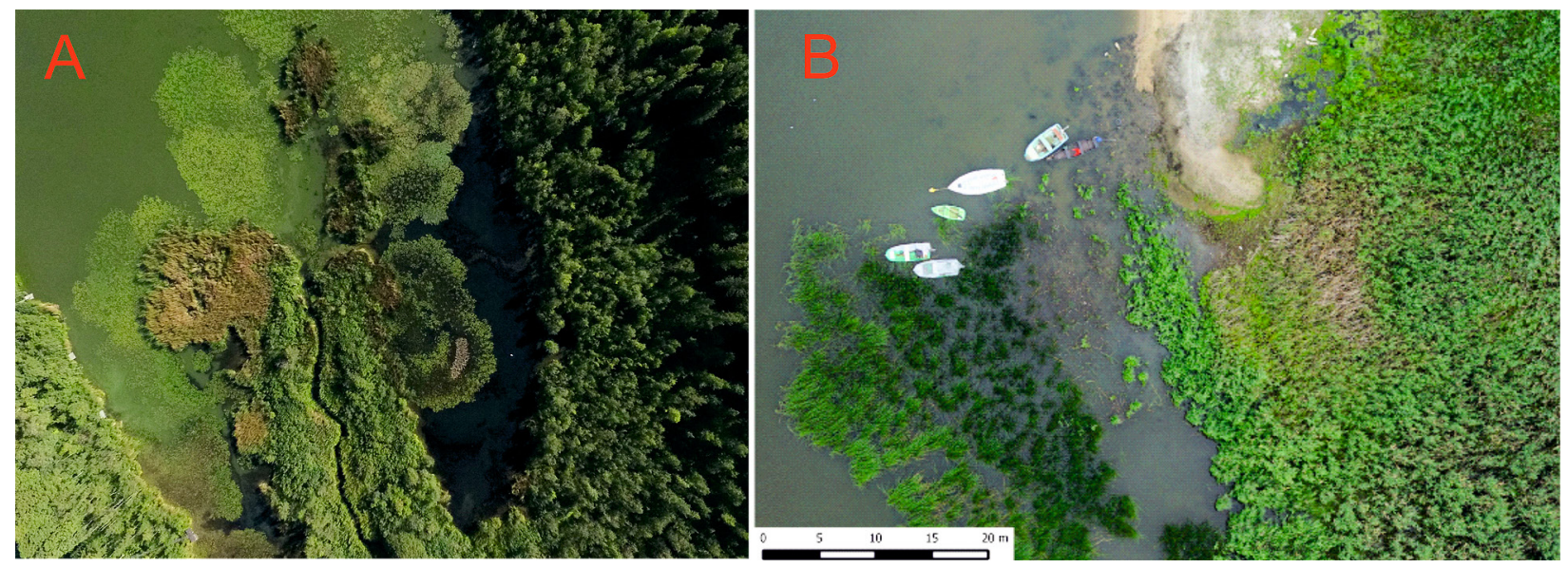

Fig. 7. Influence of the Dojca River to Lake Wolsztyńskie (A) and the accessibility of the shores of the Lake Zbąszyńskie (B). 
or other cartographic studies are most commonly used. In order to obtain the current state of development of the zones of the lakes studied, orthophotomaps of the research area were made on the basis of photographs taken from the UAV.
Thanks to the low ceiling of the flight, a very high resolution map was obtained, which enables digital zooming of even small terrain details. Such orthophotomaps can also be used as ancillary maps for design purposes, facilitating the selection of
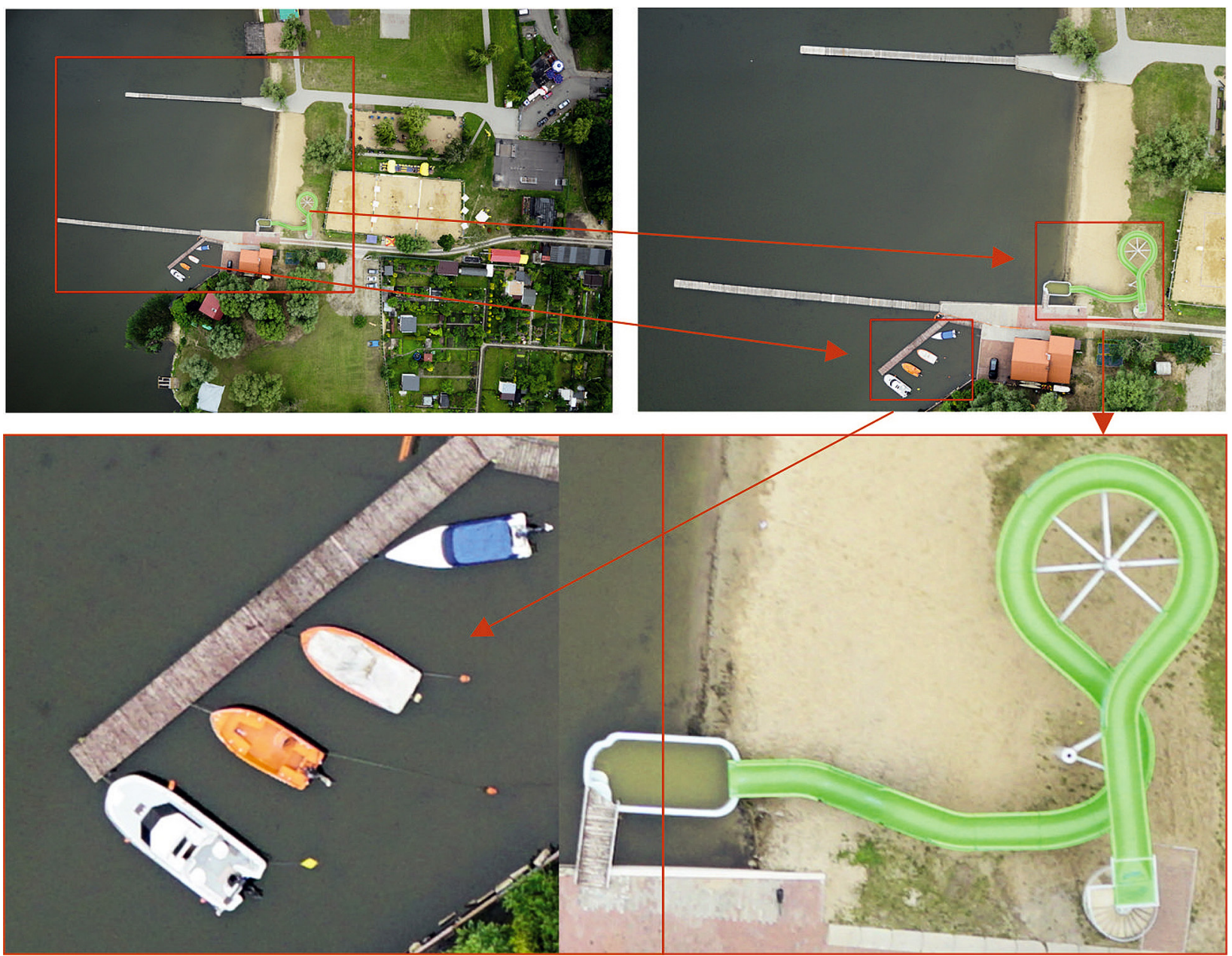

Fig. 8. Assessment of the condition of recreational infrastructure on the example of a city beach on the Lake Zbąszyńskie.

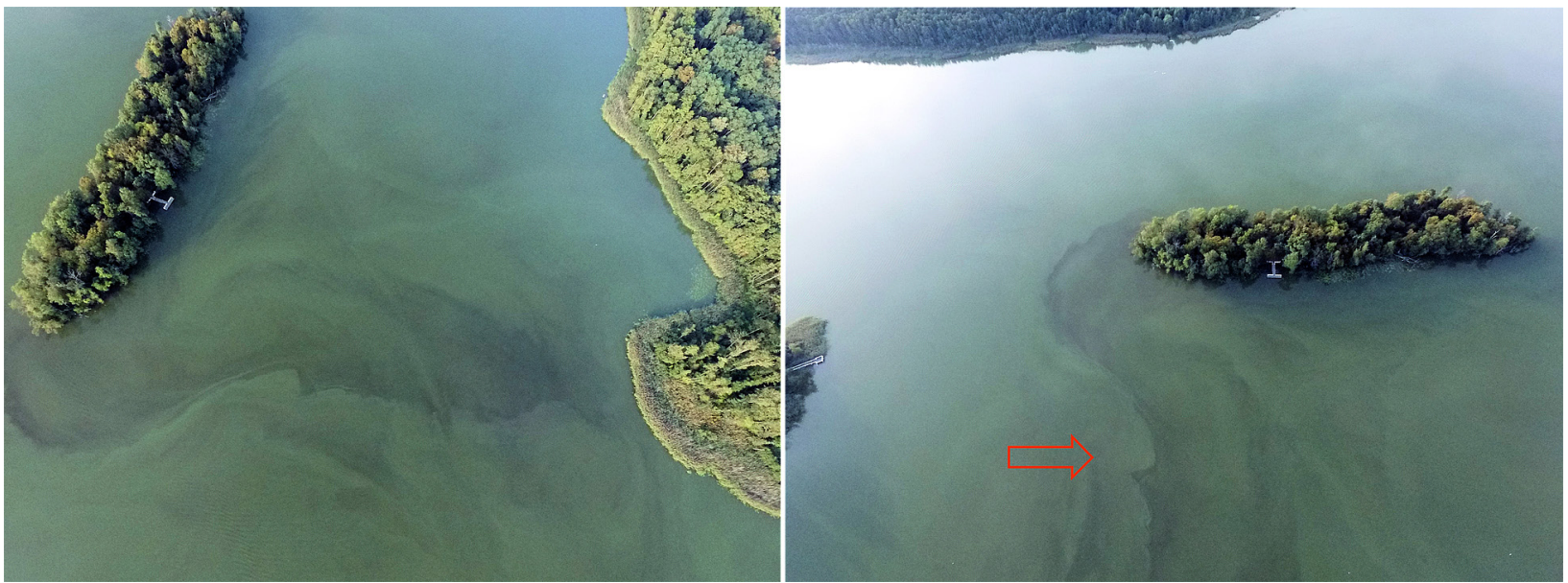

Fig. 9. Monitoring of pollution movement on the example of blooms in Lake Wolsztyńskie. 


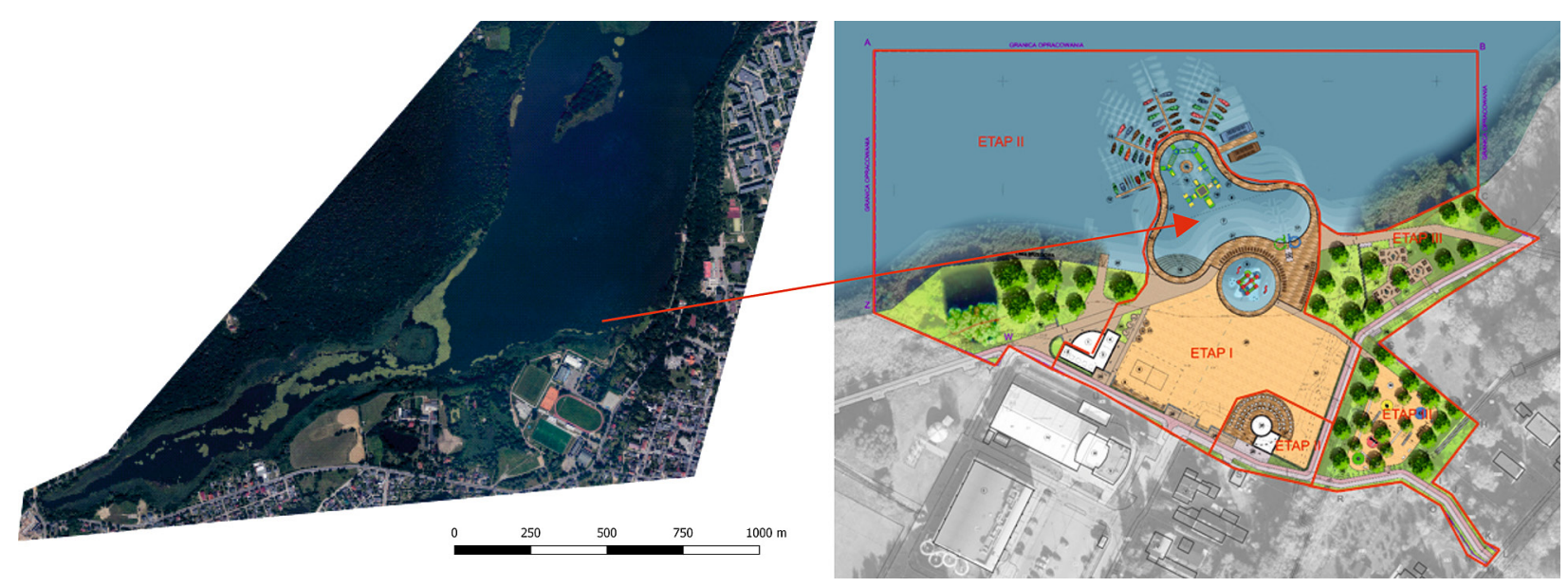

Fig. 10. Ortophotomap of the Lake Swarzędzkie presenting the current state of reservoir management (prepared by M.Wyczałek) and as an auxiliary map for design purposes (prepared by M.Szapiel).

location of investments on lakes to local conditions. An example of the orthophotomap of the Lake Swarzędzkie and the project of investment in recreational infrastructure and greenery is presented in Figure 10.

The precise determination of the shoreline is a big problem for natural water reservoirs. The course of shorelines change over time due to overgrowth and shallowing of lakes, change in the water table level or recreational use of reservoirs, while knowledge of the boundary between land and water is necessary to establish geodetic boundaries of plots, plan investments or for determining the surface of a body of water. For the above reasons, the shoreline of the Lake Swarzędzkie was established. Since a large part of the shore is unavailable neither from the land nor from the water due to the occurrence of rush and water vegetation, it was decided to determine the

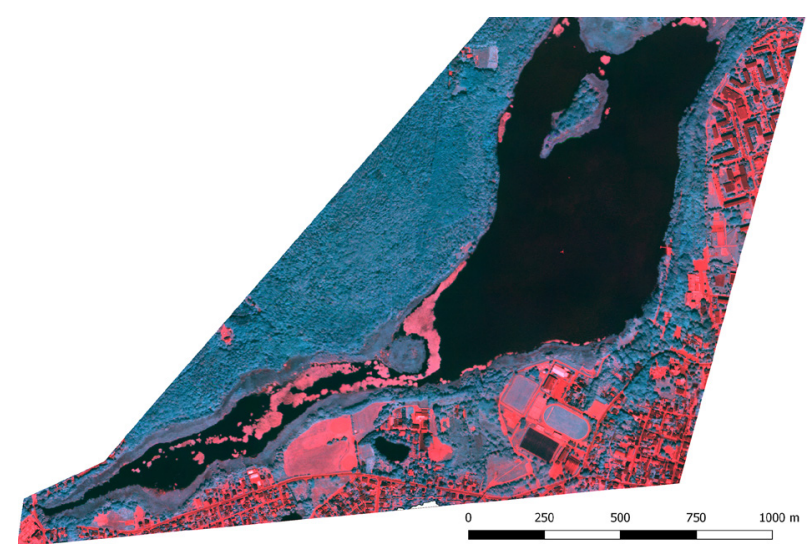

Fig. 11. A picture of the Lake Swarzędzkie in near infrared to establish the course of the shoreline and the surface of the basin (prepared by M.Wyczałek). shoreline using UAVs. Photographs taken from high altitude in the visible light range are insufficient, because the vegetation growing on the shore zone, including tree crowns, obscures the contact of water with the mainland, which is why it was decided to use a multispectral camera. Analysis of the obtained materials showed the usefulness of spectral images in the near-infrared range, on which the curve of spectral reflection of vegetation makes it possible to determine the land-water contact (Fig. 11).

\section{Conclusions}

Unmanned aerial vehicles are widely used as carriers of devices used for remote sensing. The conducted research on lakes used for tourism and recreation indicate that remote sensing methods with the use of drones are very helpful in assessing the value and development of river and lake systems and bring a new quality in relation to the methods used from the surface of the earth or water. This applies in particular to hard-to-reach areas, which are difficult or even impossible to reach from land or water, such as, for example, overgrown coastal zones or the area of inflow/outflow of a watercourse. Thanks to UAV flights, it is possible to assess the navigation of waterways and the assessment of infrastructure within them.

Another important aspect is the possibility of developing a current orthophotomap, which can be used for design purposes, as well as for visualizing the planned investment in existing 
conditions. Remote sensing methods allows monitoring of water quality, which is of particular importance in the bathing season when there is a legal obligation to visually monitor water. Pictures of water bodies made from a bird's eye view give the opportunity not only to assess, but also to anticipate threats to the quality of water, especially in the context of the occurrence of blooms.

In addition to the possibilities described in this article, UAVs find a number of other applications for lake research, depending on research needs, available sensors and funds. Using the radiation range in the infrared range, it is possible to monitor the growth of the rush vegetation biomass, plan reed removal from the coastal zone, or detect illegal felling of trees. Photographs in the visible area allow for the control of bivouacs, tent fields, and the degree of interference in legally protected areas, as well as inventory and compliance of buildings with spatial development plans around lakes. The use of drones changes the philosophy of control of tourist and recreational use of lake areas. Regularly created orthophotomaps and DSMs enable the monitoring of both natural processes occurring in nature (bank abrasion, reservoir overgrowth, water quality) and anthropopressure.

\section{Acknowledgments}

The authors wish to thank anonymous reviewers for their valuable suggestions and corrections.

\section{Author's contribution}

The authors divide the contribution percentage as follows: Grzegorz Borkowski - 80\%, Adam Młynarczyk - 20\%.

\section{References}

Borkowski G., 2014. Funkcjonowanie jezior w holocenie na przykładzie Jeziora Zbąszyńskiego. Bogucki Wydawnictwo Naukowe, Poznań: 1-138.

Choiński A., Borkowski G., 2008. Waloryzacja jezior dla potrzeb turystyki i wypoczynku. In: Z. Młynarczyk, A. Zajadacz (eds.), Uwarunkowania i plany rozwoju turystyki. T. I. Przyrodnicze zasoby turystyczne i metody ich oceny. Wydawnictwo Naukowe UAM, Poznań: 35-57.

Eltner A., Baumgart P., Maas H.G., Faust D., 2015. Multitemporal UAV data for automatic measurement of rill and interrill erosion on loess soil. Earth Surface Processes and Landforms 40(6): 741-755.

Królewicz S., Wyczałek M., Ceglarek J., Piekarczyk J., Kaźmierowski C., Lewińska K., Herodowicz K., 2015. Geodezyjna ocena dokładności ortofotomapy i cyfrowego modelu powierzchni terenu kampusu WNGIG wykonanej na podstawie zdjęć fotograficznych z UAV. In: M. Rosała, G. Kowalewski (eds.), Varia. Prace z zakresu geografii i geologii. Bogucki Wyd. Naukowe, Poznań: 17-29.

Phantom 3 Advanced User Manual v. 1.0, 2015. http:// download.dji-innovations.com/downloads/phantom_3/en/Phantom_3_Advanced_User_Manual_v1.0_ en.pdf (accessed: 15.12.2018).

Piekarczyk J., Kaźmierowski C., 2015. Przykład zastosowania obrazu Landsat 8 do rozpoznawania cech siedlisk leśnych na terenie Parku Narodowego Bory Tucholskie. In. M. Kunz (ed.), Stan poznania środowiska przyrodniczego Tucholskiego Parku Krajobrazowego i Rezerwatu Biosfery Bory Tucholskie. Wydział Nauk o Ziemi UMK, Torun: 124-134.

Rozporządzenie Ministra Zdrowia z dnia 8 kwietnia 2011 r. w sprawie prowadzenia nadzoru nad jakościa wody w kapielisku i miejscu wykorzystywanym do kapieli (Dz.U. 2011 nr 86 poz. 478 z późn. zm.),

Strejczek-Jaźwińska P., Wężyk P., Zięba-Kulawik K., Jaźwiński J. 2018. Wstępne wyniki badań z wykorzystania bezzałogowych statków powietrznych BSP (UAV) w monitoringu chomika europejskiego (Cricetus cricetus). Poszerzamy Horyzonty 9: 360-370.

Wójtowicz M., Wójtowicz A., Piekarczyk, J. 2016. Application of Remote Sensing Methods in Agriculture. Communications in Biometry and Crop Science 11(1): 31-50.

Zawiła-Niedźwiecki T., 2010. Teledetekcja i fotogrametria obszarów leśnych. In: Geomatyka w Lasach Państwowych. Część I. Podstawy, Centrum Informacyjne Lasów Państwowych, Warszawa. 